\title{
Influence of systems of basic cultivation of soil upon the content of accessible moisture and productivity of corn in Right-bank Foreststeppe region
}

\author{
S. Tanchyk, \\ Doctor of Sciences in Agriculture, Professor, \\ Head of the Department of Agriculture and herbology \\ Ya. Mykolenko \\ Postgraduate, Department of Agriculture and herbology \\ National university of life and environmental sciences of Ukraine
}

The purpose. To study influence of systems of basic soil cultivation upon the content of accessible moisture and productivity of corn. Methods. Field, calculation-mathematical, visual. Results. Results of study of influence of the basic soil cultivation upon water-and-physical properties of soil and productivity of corn are submitted for consideration. It is fixed that the system of zero cultivation promotes more efficient preservation of soil moisture for formation of yield of corn in comparison with traditional one. Conclusions. The gained results have shown that zero cultivation of soil secure available water capacities which were $20,5 \mathrm{~mm}$ more as compared to ploughing cultivation. The highest productivity of corn is gained at zero and surface cultivation.

Key words: soil, moisture content, corn, productivity, quotient of water requirement.

At the steppes of Ukraine corn grows better after winter, legumes and sugar beet. On the black earth soils stretch to grow corn can be subject to annual organic fertilizers over 6-10 years. But permanent cultivation causes deterioration of the phytosanitary situation in crops, leading to the spread of pests, diseases, weeds resistant to herbicide application [1].

In Ukraine, one of the limiting factors of high performance culture is insufficient stock available soil moisture [2]. Systems for primary tillage is not only unproductive reduce its loss, but also increase the amounts of moisture in it [3].

To obtain high yields of corn require sufficient moisture reserves in the soil as in the initial stages, and during the growing season crops. One of the measures is effective control of weed-infested, conduct basic soil in optimal terms without delay with the terms. Corn unevenly uses moisture during the growing season. Corn transpiration ratio is $250-300$, but the total demand in the moisture it great because it creates a large biomass [4].

Corn less demanding to moisture in the first half of the growing season. Most plants need moisture for 10 days prior to the ejection of panicles when held intensive growth stems (daily growth can reach 10-14 $\mathrm{cm}$ ) and accumulated solids. In this critical period is $40-50 \%$ of total water consumption. Within 20 days after the ejection of panicles need moisture decreases[9]. Many corn uses water during grain filling. It leverages rain in late summer[8]. But at the same time, corn does not tolerate waterlogged soil, dramatically reducing yields. Due to lack of oxygen in the waterlogged soil slows flow of phosphorus in roots, which affects protein metabolism [5].

The aim of our research is to clarify changes in the number of available soil moisture under various systems of its main cultivation, harvest value, the total maize weediness agrocenosis, which were a precursor crops.

Chart of experience and method of researches. Researches were conducted during 2014 - 2016 in the scientific laboratory of department of agriculture and herbology in the conditions of VP ADS NUBiP 
Ukraine of s. Pshenichne the Vasil'kivskogo district of the Kiev area. Soil on the experimental field is black earth typical little humus coarse silt - $s$ medium loam for grading. Table of contents of humus in a topsoil 3,9\%, pH $-7,3$, capacity of absorption of $32,5 \mathrm{mg}$-ekv on 100 grammes of soil.

The first experiment. The scheme provides for the experiment study of basic soil group in the rotation.

The scheme of crop rotation in field corn-row rotation corresponds zonal forest-steppe conditions:

alfalfa - winter wheat - sugar beet - maize silage - winter wheat - maize - peas - winter wheat - sugar beet - barley sowing of alfalfa.

The system of primary tillage in crop rotation:

Differential (control), by rotation of the rotation $6 x$ cultivation of the soil at different depths plowing, 2times the surface soil under winter wheat after peas and corn silage and 1 single tillage flat barley under cultivation;

Tillage flat, flat loosening at different depths soil for all crops rotation, in addition to surface soil under winter wheat in the fields mentioned above;

Ploughing -moldboardless: carrying out by rotation of rotation 2 single plowing under sugar beets, surface soil under winter wheat in the fields above and flat loosening in other cultures;

Surface: cultivation of disk tools depth of $8-10 \mathrm{~cm}$ in all cultures rotation.

Experiment second - crop rotation scheme in short rotation three-field crop rotation corresponds zonal forest-steppe conditions: soybean - barley - corn grain.

The system is composed of processing on the basis of the presence and absence of tillage and herbicide use and solid ground action:

Industrial (control) - the use of tillage (primary - disking after harvesting the precursor to a depth of 6-8 $\mathrm{cm}$, plowing to a depth of $20-22 \mathrm{~cm}$ presowing - mulching on soil physical maturity and application of herbicides to a depth of $2-3 \mathrm{~cm}$; presowing cultivation on depth of $4-5 \mathrm{~cm}$ seed, industrial use of agrochemicals.

No-till - no tillage, protection of corn made for the use of herbicides.

General plottage $50 \mathrm{~m}^{2}$, the repeated is fourfold. Variants are placed the method of the split areas.

Currently, fixed data experiences is the longest in Ukraine.

Inventories of available moisture determined by weight in the layer bent 0-100 sm, total water consumption and water consumption rate of corn - calculation method, productivity - the accounting area of $25 \mathrm{~m}^{2}[4]$.

Weather conditions during the research were typical right-bank steppe zone. The average long-term rainfall $-555 \mathrm{~mm}$ during the growing season falls an average of $310 \mathrm{~mm}$. The average long-term temperature is $+7,2^{\prime} \mathrm{C}$.

The total rate of water consumption crops expected results for the dynamic parameters of soil moisture. Based on our data on the systems primary tillage fixed stock of available moisture in the 0-100 $\mathrm{cm}$ layer at the beginning of the growing season, the flowering phase and the end of the growing season crops.

Results of researches. The results of the research showed that the sowing period for zero soil moisture reserves available were higher by $20.5 \mathrm{~mm}$ compared to plowing.

Based on the data found in the studied variants stock of available moisture in the layer $0-100 \mathrm{~cm}$ at the beginning and end of the growing season. Reported that in the beginning of growth for core and surface tillage moisture reserves in the soil exceeded this figure in control of $15.6 \mathrm{~mm}$, and at the end of the growing season - $20.9 \mathrm{~mm}$, respectively. In experiments on zero tillage in early vegetation moisture content accessible exceeded this figure in control to $23.6 \mathrm{~mm}$., And at the end of the growing season $13.7 \mathrm{~mm}$ on average during the years of the study.

The method of mathematical calculations and statistical data determined the total water consumption and water consumption rate of corn. Number of water wasted by plants and soil on the formation of 1 ton harvest, called the water.

The results show that the economical use wet surface at zero and cultivation. For zero tillage can be explained by the presence mulching layer on the soil surface, which prevents excessive evaporation of 
moisture. Surface soil retains moisture in the soil by crushing the soil surface, that is also known mulching the soil, which prevents evaporation of moisture.

The mathematical calculations and statistical analysis indicates that the greatest impact on the rate of water system had superficial tillage. In the second experiment recorded the highest rate of water consumption by ploughing on a depth cultivation.

Most economical use moisture to form a crop for zero tillage and for ploskoriznoho that $31.7 \mathrm{~mm} \backslash \mathrm{t}$ less than in the controls ( the first experiment $30.8 \mathrm{~mm} / \mathrm{t}$., the second experiment $-64.4 \mathrm{~mm} / \mathrm{t}$ ).

The main summary indicator is the yield of crops. At the time of processing of statistical data and traced yield increases for various flat cultivation of $1.4 \mathrm{t} /$ ha and $0.5 \mathrm{t} /$ ha of surface soil compared to the control.

For zero tillage increased yield of $0.5 \mathrm{t} /$ ha compared with a control option in the second experiment.

\section{Conclusion}

So for the formation of a crop of corn for grain moisture is most effectively used for zero tillage in short rotational crop rotation after spring barley. In the 10th rotation of the fields most efficient plane was different tillage on winter wheat.

\section{References}

1. Толорая T.P. Роль водопотребления в повышении продуктивности кукурузы/Т.Р. Толорая, В.П. Малаканова//Кукуруза и сорго. - 2001. - № 4. - С. 2 - 3.

2. Бука А.Я. Влагообеспеченность почвы при разных способах обработки/А.Я. Бука, С.Ю. Булыгин, А.П. Коваленко//Земледелие. - 1985. - № 11. - С. $10-12$.

3. Доспехов Б.А. Методика полевого опыта с основами статистической обработки результатов исследований/Б.А. Доспехов. -4-е. изд. перераб. и доп. - М.: Колос, 1979. -416 с.

4. Лабораторно-практичні заняття по землеробству: навч. посіб./О.П. Кротінов, І.П. Максимчук, Ю.П. Манько, І.С. Руденко. - К.: Вид-во УСГА, 1993. - 280 с.

5. Методика проведення польових дослідів з кукурудзою/Є.М. Лебідь, В.С. Циков, Ю.М. Пащенко та ін. - Дніпропетровськ, 2008. - 27 с.

6. Малієнко А.М. Напрям розвитку і сучасні тенденції технологій обробітку ґрунту/А.М. Малієнко//Посібник укр. хлібороба: наук.-практ. щорічник. - 2010. - С. 91 - 93.

7. Єрмолаєв М.М. Водний режим чорнозему типового в короткоротаційних зернових сівозмінах/М.М. Єрмолаєв, Л.І. Шиліна, Д.В. Літвінов//Зб. наук. пр. Ін-ту землеробства УААН. 2002. - Спецвипуск. - С. $161-166$.

8. Косолап М.П. Системаземлеробства notill/М.П. Косолап, О.П. Кротінов. -К.: Логос, 2011.C. 352 .

9. Потенціали родючості ґрунтів і продуктивність сільськогосподарських культур/Г.А. Мазур, М.М. Єрмолаєв, М.А. Ткаченко, П.Д. Гринчук//Зб. наук. пр. Ін-ту землероб. УААН. - К., 2002. Вип. $3-4 .-$ С. $3-7$.

10. Brandt S.A. Crop production under alternative rotations on a dark brown chernozemic soil at Scott/S.A. Brandt, R.P. Zentner//Can. J. Plant Sci. — Saskatchewan. — № 5. - 1995. - P. 789 - 794 